\title{
EU LAW AND THE DISCRETION OF PRIVATE NATIONAL DECISION-MAKERS IN LIGHT OF THE COURT'S JUDGMENT IN CASE C-22/18 TOPFIT AND BIFFI
}

\author{
ANGELICA ERICSSON*
}

This contribution aims to introduce the reader to a judgement from the Court of Justice which seems to broaden the scope of application of $E U$ free movement rules to private regulatory bodies in two ways. One the one hand, this judgment expands our understanding of what type of private regulation can fall within this scope. On the other hand, it shows that EU law requires a private prior authorisation scheme to be infused with the same objectivity safeguards as those that have been required for public ones.

\section{EU LAW, NATIONAL ADMINISTRATIVE DISCRETION AND LEGAL AUTONOMY OF PRIVATE ACTORS}

The focus of this piece will be the application of EU administrative law principles to certain private decision-makers and how this affects their legal autonomy. When one speaks of the power of private entities to take decisions, this power can generally be described as legal autonomy rather than discretion - conveying the idea that the capacity of private entities, as opposed to public ones, is not inherently limited by law. ${ }^{1}$ Before going into the article's main feature, the judgment handed down by the EU's Court of Justice ${ }^{2}$ in the TopFit and Biffi case, ${ }^{3}$ I will start by briefly elaborating on the two EU law themes that are most relevant to the set focus, namely the development of an EU administrative law shield against arbitrary national decision-making and the application of EU Treaty rules to private actors. Later, in sections 3 and 4 of this case note, you will find my analysis of the impact said judgment has had on these themes. The last section will provide some brief final conclusions.

\subsection{AN EU ADMINISTRATIVE LAW SHIELD AGAINST ARBITRARY NATIONAL DECISION-MAKING}

It follows from the Treaty on the Function of the European Union (TFEU) that Member States should not hinder EU free movements, at least not in an unjustified manner. This, in itself, is a fairly uncontroversial statement. What has been more controversial, and what has

\footnotetext{
* PhD Candidate, Faculty of Law, Lund University. I would like to extend my heartfelt thanks to Françoise Blum and Lukas Zöllner for their input at an early stage of my work with this article. The usual disclaimer applies.

${ }^{1}$ In contrast, if one accepts that the existence and power of public entities are justified by and through public law, their power to choose between different actions could only ever be described as discretion - never as autonomy.

${ }^{2}$ Henceforth, referred to as 'the Court of Justice' or simply 'the Court'.

${ }^{3}$ Case C-22/18 TopFit and Biffi EU:C:2019:497.
} 
consistently generated significant political and academic debate over the years, is the Court's interpretation of what should be qualified as unjustified restrictions of the EU free movements.

In relation to different kinds of national prior authorisation schemes, the Court of Justice has developed an EU administrative law shield against arbitrary national decisionmaking, including a set of requirements which I have chosen to call 'objectivity safeguards'. ${ }^{4}$ In more concrete terms, the Court has developed case-law where it demands that such authorisation schemes - when they can potentially restrict the EU free movements - must be based on accessible, objective and non-discriminatory criteria which are known in advance and that the decisions to refuse authorisation must be reasoned, taken in a timely manner, and subject to effective judicial review. ${ }^{5} \mathrm{By}$ their nature, these required objectivity safeguards are closely tied to general principles of administrative law - as found both in EU law and in domestic legal orders such as the principles of legality, equal treatment, transparency, good administration and access to effective judicial protection. All these principles are designed to maintain the rule of law, by providing safeguards against arbitrary decisions by public entities.

In this article, I would like to highlight that the development of such objectivity safeguards, despite their distinctive 'administrative law flavour', may have constitutional law impacts on national legal orders that reach beyond the traditional realm of administrative law, in the sense that not only the discretion of public, but also private, national decisionmakers would be affected. Hence, my analysis will draw attention to the imposition of such uncodified 'administrative law'-type EU requirements on private national decision-makers. It is in this light that I will discuss the Court's judgment from the $13^{\text {th }}$ June 2019 in the TopFit and Biffi case.

In section 4 below, it will be specifically considered whether, in light of this judgment, also private actors who put into place a prior authorisation scheme are bound by EU law to infuse it with objectivity safeguards. But first, in sub-section 1.2, the application of EU Treaty rules to private actors will be considered more broadly, as a background to the analysis in sections 3 and 4 .

\subsection{APPLICATION OF EU FREE MOVEMENT RULES TO PRIVATE ACTORS}

Do the EU free movement rules only concern public entities, or do they also prohibit private entities ${ }^{6}$ from discriminating on the basis of nationality? Hans Ragnemalm, a former judge at the Court of Justice, once noted that as long as private undertakings do not affect competition, their discriminatory conduct is not normally regarded as being contrary to the

\footnotetext{
${ }^{4}$ After abandoning the conceptual candidates used previously to describe these requirements in Angelica Ericsson, 'Structural Guarantees - the Union's Last Best Hope against National Arbitrariness' (2010) 13 Europarättslig tidskrift 237 and Angelica Ericsson, 'The Role of the Court in Limiting National PolicyMaking : Requiring Safeguards against the Arbitrary Use of Discretion’ in Johan Lindholm and Mattias Derlén (eds), The Court of Justice of the European Union: Multidisciplinary Perspectives (Hart Publishing 2018). ${ }^{5}$ See eg Case 304/84 Muller EU:C:1986:194, Case 178/84 Commission v Germany (German Beer) EU:C:1987:126 and Case C-672/15 Noria Distributions EU:C:2017:310, as well as Sacha Prechal, 'Free Movement and Procedural Requirements: Proportionality Reconsidered' (2008) Legal Issues of Economic Integration 201. ${ }^{6}$ Understood as natural and legal persons.
} 
Treaty rules on free movement. ${ }^{7}$ In particular, he argued that even if early case-law pointed into the other direction, the Court of Justice seems to have settled on the premise that EU rules on the free movement of goods only concern acts of public authorities and not acts of private undertakings. ${ }^{8}$ However, if private actors would effectively manage to disturb trade in goods, the Court has made clear that the Member States - due to their duty of loyal cooperation - are judicially accountable if they don't take action to prevent such disturbances.

Moreover, we can deduce from the Court's case-law that some entities constituted under private law might still carry the same responsibilities as public authorities, for the purposes of the legal obligations laid down in directives, even if such legal acts can normally not be relied upon against private entities. In fact, building on its own statements in the Foster case,${ }^{10}$ the Court of Justice has declared that

'a body or an organisation, even one governed by private law, to which a Member State has delegated the performance of a task in the public interest and which possesses for that purpose special powers beyond those which result from the normal rules applicable to relations between individuals is one against which the provisions of a directive that have direct effect may be relied upon'. ${ }^{11}$

Also in relation to directives, Azoulai has discussed how the Court can use a constitutional principle, if it is the 'superior expression' of the specific provisions of the nonapplicable directive, to create rights and obligations that the national court has the obligation to protect in any private litigation. ${ }^{12}$ This technique, which is rooted in the famous Defrenne case, ${ }^{13}$ has resurfaced in other disputes against private employers, such as the cases Kücükdeveci ${ }^{14}$ and Egenberger. ${ }^{15}$

Shifting our focus back to the application of the Treaty rules on free movement, the foundations for the invocability of the free movement of workers and the freedom of establishment against private entities are to be found in the Walrave and Koch case. ${ }^{16}$ In its judgment in this case, the Court of Justice used a pragmatic approach to assure effectiveness of EU law. It held that the prohibition against discrimination on the basis of nationality does not only apply to the action of public authorities but also extends to rules of any other nature aimed at regulating in a collective manner gainful employment and the provision of services,

\footnotetext{
${ }^{7}$ Hans Ragnemalm, 'Fundamental Freedoms and Private Action: A New Horizon for EU Citizens?' in Hans Ragnemalm and Mats Melin, EG-Domstolen Inifrän: Uppsatser Om Och Kring Rättskipningen Inom EU (Jure 2006) 183.

${ }^{8}$ Hans Ragnemalm, 'Fundamental Freedoms and Private Action: A New Horizon for EU Citizens?' (n 7), $183 \mathrm{f}$ and K.J.M. Mortelmans, 'The Functioning of the Internal Market: The Freedoms' in PJG Kapteyn (ed), The Law of the European Union and the European Communities: With Reference to Changes to Be Made by the Lisbon Treaty (4 $4^{\text {th }}$ rev. edn, Kluwer 2008) 636.

${ }^{9}$ See Case C-265/95 Commission v France (French farmers) EU:C:1997:595 and Case C-112/00 Schmidberger EU:C:2003:333

${ }^{10}$ Case C-188/89 Foster and Others EU:C:1990:313.

${ }^{11}$ Case C-413/15 Farrell EU:C:2017:745, para 35.

${ }^{12}$ Loïc Azoulai, 'The Case of Fundamental Rights: a State of Ambivalence' in Hans-W Micklitz and Bruno

De Witte, The European Court of Justice and the Autonomy of the Member States (Intersentia 2012) 215.

${ }^{13}$ Case 43/75 Defrenne EU:C:1976:56.

${ }^{14}$ Case C-555/07 Kücü̈edeveci EU:C:2010:21.

15 Case C-414/16 Egenberger EU:C:2018:257.

${ }^{16}$ Case 36/74 Walrave and Koch EU:C:1974:140.
} 
since the abolition as between Member States of obstacles to freedom of movement for persons and to freedom to provide services would be compromised if the abolition of barriers of national origin could be neutralized by obstacles resulting from the exercise of their legal autonomy by associations or organisations which do not come under public law. ${ }^{17}$ This formula was later reiterated by the Court in the Bosman case ${ }^{18}$ and the Laval case. ${ }^{19}$ What can be clearly concluded from this case-law is that a group or organisation that can exercise a certain power over private individuals, and is able to impose conditions as a result of which the exercise of EU fundamental freedoms may be hindered, can be held accountable against the Treaty rules concerning those freedoms. ${ }^{20}$

Furthermore, cases like Angonese $e^{21}$ and Raccanelli2 ${ }^{22}$ suggest that also a private entity which is not a collective regulatory body, like a sports association or a trade union, can be held accountable against the fundamental freedom of workers. Timmermans has argued that the reasoning of the Court of Justice in the Ferlini case $^{23}$ suggests that the Court will, however, be more reluctant to admit such horizontal effect to the fall-back prohibition against discrimination on the basis of nationality, found in Article 18 TFEU, than to the free movement of workers. ${ }^{24}$ On the other hand, the Court recently avoided the chance to expressly refute that Article 18 TFEU would be capable of producing independent horizontal direct effect in the TÜV Rheinland case, ${ }^{25}$ meaning that the last word is not said on the issue.

\section{GETTING ACQUAINTED WITH THE TOPFIT AND BIFFI CASE}

The TopFit and Biffi case might have passed under the radar for many EU law scholars, at least if they are not specialised in sports law, given that it was not judged by the Court's Grand Chamber. However, I would suggest that this case is well worth getting acquainted with, if one is interested in the themes outlined above.

\subsection{THE FACTS OF THE CASE}

The TopFit and Biffi case originated in a German civil law dispute between private parties, concerning the possibility for an Italian amateur sprinter, Mr. Biffi, to compete in German championships. Although retaining his Italian nationality, Mr. Biffi can certainly be considered to have settled in Germany, where he not only works but also lives with his family. He has been a resident there since 2003 and besides competing in track and field running races, he runs a business in which he provides services as an athletics coach and personal trainer.

\footnotetext{
${ }^{17}$ Case 36/74 Walrave and Koch EU:C:1974:140, paras 17 and 18.

${ }^{18}$ Case C-415/93 Bosman EU:C:1995:463.

${ }^{19}$ Case C-341/05 Laval EU:C:2007:809.

${ }^{20}$ P.J.G. Kepteyn, 'The Application and Enforcement of Community Law in the National Legal Systems' in

Kapteyn (n 8) $532 \mathrm{f}$.

${ }^{21}$ Case C-281/98 Angonese EU:C:2000:296.

${ }^{22}$ Case C-94/07 Raccanelli EU:C:2008:425.

${ }^{23}$ Case C-411/98 Ferlini EU:C:2000:530.

${ }^{24}$ C.W.A. Timmermans, 'The Basic Principles' in Kapteyn (n 8) 163.

${ }^{25}$ Case C-581/18 TÜV Rheinland LGA Products and Allian₹ LARD EU:C:2020:453.
} 
Together with the Berlin-based athletics club Topfit which he was a member of, Mr. Biffi had challenged the application of new rules governing the right to participate in national athletics championships. These rules were adopted and applied by the DLV, the federal umbrella association for German athletics associations, which organises these championships.

According to the DLV's former rules, Mr. Biffi could - and did - participate in the senior category of the national athletics championships. Quite successfully, too. However, according to the DLV's new rules, his continued participation in these championships could only ever be partial, if not barred completely. In fact, henceforth, he could either be refused to participate altogether, based on his nationality, or be allowed to participate but without classification or access to the final. In other words, even if he would be authorised to compete in a national championship, his achievement would not be part of the competition's resulting ranking.

The DLV justified its new rules by claiming that only an athlete of German nationality who can participate in international championships under the abbreviation 'GER', which refers to the word 'Germany', should be the German champion. Furthermore, the DLV claimed that it would be impossible to have rules for senior sport that diverge from those applicable to other age categories. In any event, according to the DLV, since Mr. Biffi's participation in athletics championships would not constitute an economic activity, this participation - and any rules restricting it - would fall outside the scope of EU law.

The Local Court of Darmstadt - responsible for dealing with the dispute between Mr. Biffi, his club and the DLV - agreed that he, despite his impressive sporting achievements, remains an amateur sportsman who is not exercising an economic activity when he participates in championships. However, this national court was unsure whether the application of EU law in the area of sport is always subject to the exercise of an economic activity. In that regard, it observed that, after the entering into force of the Lisbon Treaty, EU law explicitly refers to sport in Article 165 TFEU and that the right of EU citizens to reside in another Member State without discrimination, in accordance with Articles 18, 20 and 21 TFEU, is not dependent on the exercise of an economic activity. Hence, by way of reference for a preliminary ruling, this court asked the Court of Justice if these Treaty provisions should be interpreted in the sense that the DLV's new rules should be considered as unlawful discrimination, contrary to EU law.

\subsection{ADVOCATE GENERAL TANCHEV'S OPINION}

Although the referring court had apprehended the dispute before it as one primarily concerned with EU citizenship and its relationship with both the prohibition on discrimination on the basis of nationality and the promotion of European sporting issues, Advocate General Tanchev made a different assessment. In his Opinion, he instead claimed that what was at issue in this dispute was a restriction, founded on discrimination based on nationality, of Mr. Biffi's freedom of establishment under Article 49 TFEU. ${ }^{26}$

To justify this reassessment of the dispute, the Advocate General highlighted several factual elements that had emerged at the hearing before the Court, specifically that Mr. Biffi

\footnotetext{
${ }^{26}$ Case C-22/18 TopFit and Biffi EU:C:2019:181, Opinion of AG Tanchev, para 48.
} 
earns his living via sports training and that the title of national champion for Germany would be a valuable and important addition to Mr. Biffi's business card, in the exercise of his economic activity. In the light of these elements, the argument put forward is that Mr. Biffi cannot be regarded as an 'amateur' sportsman, even if he competes in 'amateur' championships. $^{27}$

The Advocate General came to the conclusion ${ }^{28}$ that, principally due to the absence of a transitional rule to account for the established rights of EU citizens like Mr. Biffi, who have already acquired the right to compete on an equal footing with nationals of their host Member State, after having exercised their rights to 'move and reside freely' there, the DLV has acted inconsistently with Mr. Biffi's rights to freedom of movement under EU law, and more specifically his freedom of establishment under Article 49 TFEU. He further concluded that the restriction imposed by the DLV is, in these circumstances, disproportionate.

These conclusions primarily relied on an indirect impact of the DLV's new rules on the economic activities of $\mathrm{Mr}$. Biffi ${ }^{29}$ and the general principle of respect for acquired rights - which would justify a departure, in this particular case, from a general deference to national margin of discretion in regards to rules of purely sporting interest. ${ }^{30}$ Hence, the Advocate General essentially proposed a solution where the Court of Justice could assure that Mr. Biffi and his athletics club would win their pending case before the local court, while generally preserving the status quo of national divergences in sporting rules and avoiding to take the ‘significant constitutional step' of giving Article 21 TFEU horizontal applicability. ${ }^{31}$

\subsection{FINDINGS OF THE COURT}

The Court, however, seems to have been more comfortable with taking that constitutional step than with deciding the case with reference to Article 49 TFEU, as proposed by Advocate General Tanchev, as this Treaty provision had not been debated between the parties to the case. $^{32}$

It was found that, having exercised his right to free movement within the meaning of Article 21 TFEU, Article 18 TFEU is applicable to someone, like Mr. Biffi, who resides in a Member State other than the Member State of which he is a national and in which he intends to participate in sporting competitions in an amateur capacity. ${ }^{33}$ In this regard, the Court explicitly mentioned the access to leisure activities available in the host Member State - in particular sports, considered to be an important factor for integration - being a corollary to freedom of movement. ${ }^{34}$

Further down in the judgment, the Court recognized that it has consistently excluded certain types of sports-related discriminations based on nationality from the scope of the EU free movement rules, such as the time-honoured practices of pinning national sports teams against each other. However, it recalled that such a restriction on the scope of these rules

\footnotetext{
${ }^{27}$ Case C-22/18 TopFit and Biffi EU:C:2019:181, Opinion of AG Tanchev, paras 50 and 51.

28 As expressed at para 5 of his Opinion (n 26).

${ }^{29}$ Case C-22/18 TopFit and Biffi EU:C:2019:181, Opinion of AG Tanchev, paras 62 and 73.

$30 \mathrm{ibid}$, paras $77,80,81$ and 87.

31 ibid, para 56.

32 Case C-22/18 TopFit and Biffi EU:C:2019:497, para 24.

$33 \mathrm{ibid}$, paras 27-30, and 35.

34 ibid, paras 31-34.
} 
must remain limited to its proper objective and cannot be relied upon to exclude entire sporting activities from the scope of the Treaty. ${ }^{35}$

As for the abovementioned horizontal applicability of Articles 18 and 21 TFEU, the Court went on to examine the question whether the rules of national sports associations are subject to the rules of the Treaty in the same way as rules emanating from the state are. ${ }^{36}$ In that regard, it recalled that, in accordance with settled case-law, observance of the fundamental freedoms and the prohibition of discrimination on the basis of nationality also apply to rules which are not public in nature but which are aimed at regulating gainful employment and the provision of services in a collective manner, since the abolition as between Member States of obstacles to the freedom of movement for persons and to the freedom to provide services, which is a fundamental objective of the European Union, would be compromised if the abolition of barriers emanating from the state could be neutralised by obstacles resulting from the exercise of their legal autonomy by associations or organisations which do not come under public law. ${ }^{37}$

The Court then added that the principle established by this case-law, which specifically concerned rules restricting economic activity, also applies in cases where a group or organisation exercises a certain power over individuals and is in a position to impose on them conditions which adversely affect the exercise of the EU fundamental freedoms. ${ }^{38}$ From this statement, the conclusion was drawn that the rules of a non-public organisation such as the national sports association, which govern the access of EU citizens to sports competitions, are subject to the rules of the Treaty, in particular Articles 18 and 21 TFEU. ${ }^{39}$ Already at this point of the Court's reasoning, it became clear that the Court would not be willing to accept the DLV's argument that, as a sports association, it is autonomous and free to establish its own rules. ${ }^{40}$

The DLV's new rules were effectively deemed to constitute a discriminatory authorisation scheme for national athletics championships, which would in itself constitute a restriction to the free movement of EU citizens. ${ }^{41}$ Furthermore, given that, even if foreign athletes who are nationals of other Member States would be authorised to compete, they would still be excluded from the official competition rankings, these rules were deemed to have far-reaching effects on the integration of these athletes - not only into the sports club to which they are affiliated but also into the society of the Member State in which they are residing. According to the Court, this negative effect on integration also constitutes a restriction on the freedom of movement of EU citizens within the meaning of Article 21 TFEU. ${ }^{42}$

\footnotetext{
35 ibid, para 49.

${ }^{36}$ It is clear from the context and the French original wording of paragraph 36 of the judgment should be read in this way, even though the English version of this paragraph reads as follows: 'Nevertheless, the question arises whether the rules of national sports associations are subject to the rules of the Treaty in the same way as they are subject to the rules of the State of origin.'

${ }^{37}$ Case C-22/18 TopFit and Biffi EU:C:2019:497, paras 37 and 38, recasting the classic wording in paragraphs

17 and 18 of Case 36/74 Walrave and Koch EU:C:1974:140, discussed in section 1.2 above.

38 Case C-22/18 TopFit and Biffi EU:C:2019:497, paras 37 and 39.

39 ibid, para 40.

40 This argument was explicitly binned at paragraphs 52 and 53 of the judgment.

${ }^{41}$ Case C-22/18 TopFit and Biffi EU:C:2019:497, paras 43 and 44.

$42 \mathrm{ibid}$, paras 45-47.
} 
As for possible justifications for such restrictions on the freedom of movement of EU citizens, the Court proclaimed that,

as has been held with regard to the composition of national teams, it appears to be legitimate to limit the award of the title of national champion in a particular sporting discipline to a national of the relevant Member State and consider that nationality requirement to be a characteristic of the title of national champion itself. ${ }^{43}$

However, the argument that the public expects that the national champion of a country will have the nationality of that country does not systematically justify any restriction on the participation of non-nationals in the national championships, only the ones which are based on objective considerations and respect the principle of proportionality. ${ }^{44}$

When examining the two specific justifications put forward by the DLV, none of them appeared to be founded on the necessary objective considerations, primarily due to the fact that the DLV's mechanism for the selection of which athletes would represent Germany at an international level did not apply to the amateur categories. ${ }^{45}$ However, after firmly rejecting these justifications, the Court still left the door open for the national court to consider whether there might be others that could justify the rules establishing the 'admission-under-limiting-conditions' of non-nationals to the national championships. It also gave some concrete guidance on which elements, connected to the specific characteristics of the case at hand, to take into account for the proportionality assessment of such rules. ${ }^{46}$

Up until this point in the judgment, the Court had considered the restrictive conditions under which Mr. Biffi would be allowed to compete, if he was allowed to compete - ie the conditions that thwarted his hopes of taking a medal in a national championship or being officially ranked one of the fastest short-distance runners in Germany, even if he would get to enter the competition. But in the judgment's final couple of paragraphs, the Court turns its attention to the possibility of Mr. Biffi not being allowed to enter the national championships at all.

In this regard, the Court notes that since the participation of non-nationals is subject to an authorisation according to the DLV's new rules, such exclusion would remain possible. Citing only the judgment in the Analir case, ${ }^{47}$ the Court alludes to a long-standing pillar of EU administrative law for Member States, ${ }^{48}$ namely that, in order for a national prior authorisation scheme to be justified in the light of the free movement rules, it must, in any event, 'be based on objective and non-discriminatory criteria which are known in advance, in such a way as to circumscribe the exercise of the [decision-maker's] discretion so that it is not used arbitrarily'. ${ }^{49}$ The Court then directly moves on to declare that, since there is a mechanism for the participation of a non-national athlete in the German national championships at hand, the total non-admission of such an athlete to those championships

\footnotetext{
${ }^{43}$ Case C-22/18 TopFit and Biffi EU:C:2019:497, para 50.

$44 \mathrm{ibid}$, paras 48 and 54.

45 ibid, paras 55-58.

46 ibid, paras 59-63.

47 Case C-205/99 Analir and Others EU:C:2001:107.

${ }^{48}$ Namely the objectivity safeguards of the EU administrative law shield against arbitrary national decisionmaking that were presented in section 1.1 above.

${ }^{49}$ Case C-22/18 TopFit and Biffi EU:C:2019:497, para 65.
} 
on account of his nationality seems, in any event, to be disproportionate. ${ }^{50}$ These two paragraphs of the judgment, paragraphs 65 and 66, do not seem to have caught the interest of other scholars. ${ }^{51}$ They will, however, be more extensively analysed in section 4 of this case note.

The drafting of the answer subsequently given to the referring court in the TopFit and Biffi case is strikingly specific to the factual situation at hand. This might be a tactic from the Court to keep the possibility to back-track on its development of the case-law by distinguishing the judgment in this case on the basis of its particular facts. Looking solely at the answer given in the operative part of the Court's judgment, one gets the impression that the specific type of sport, the age category of the competitions or the length of the stay of Mr. Biffi in Germany plays a decisive role in the Court's conclusion that Articles 18, 21 and 165 TFEU, in principle, would preclude the DLV's new rules. However, in light of the rest of the judgment, I would rather argue that these parameters would find their relevance in the potential proportionality assessment that was expressly left to the referring court in this case. Moreover, the operative part of the judgment does not reflect the Court's clear and unconditional disqualification of the possibility to exclude foreign athletes, under the authorisation scheme at hand.

\section{PRIVATE DECISION-MAKERS' RESPONSIBILITY FOR INTEGRATION WITHIN THE EU}

The TopFit and Biffi case continues a longstanding tradition of cases relating to sports that pushes the boundaries of EU law-responsibilities that are put on private decision-makers without the enactment of secondary legislation. From the very beginning, ${ }^{52}$ is has been rules regulating sports activities that have laid the ground for private law entities being held accountable under EU free movement law. There is, hence, a well-established case-law providing that the prohibition on nationality-based discrimination coupled with the economic free movement rules, such as the free movement of workers and the freedom of establishment, which are mandatory in nature, must be taken into account by the national court in judging the validity or the effects of any national provision limiting those rules, also those provisions inserted in the rules of a private sporting organisation. ${ }^{53}$ Already before Bosman, but maybe particularly with this widely known case, sports federations have definitely and irrevocably lost their aura of immunity under EU law, $\cdot{ }^{54}$ Notably, it follows from the judgment in this case that the principle of subsidiarity cannot lead to a situation in which the freedom of private associations to adopt sporting rules restricts the exercise of rights conferred on individuals by the Treaty. ${ }^{55}$

\footnotetext{
50 ibid, para 66.

${ }^{51}$ See eg Richard Parrish and Johan Lindholm, 'Horizontal Direct Effect of Union Citizenship and the

Evolving Sporting Exception: TopFit' (2020) Common Market Law Review 1283.

52 With Case 36/74 Walrave and Koch EU:C:1974:140, discussed in section 1.2 above.

${ }^{33}$ Case 13/76 Donà EU:C:1976:115, paras 11, 17 and 18.

54 Stefaan Van den Bogaert, 'Bosman: One for All ...' (2015) 22 Maastricht Journal of European and

Comparative Law 174, $175 \mathrm{f}$.

55 Case C-415/93 Bosman EU:C:1995:463, para 81.
} 
However, up until it judgment in the TopFit and Biffi case, the Court had consistently held that sport is subject to EU law 'only in so far as it constitutes an economic activity'. ${ }^{56}$ As noted by Parrish and Lindholm, this stance had given rise to a well-founded impression that invoking EU law in a sporting context requires some modicum of economic nexus and that "EU law cannot be invoked in "pure" amateur sport. ${ }^{57}$ The order for reference from the German court in the TopFit and Biffi case questioned this impression and presented competing views on the relevance of economic activity as a prerequisite for the application of EU law, especially after the Lisbon Treaty had entered into force. But even if the DLV and the referring court both seemed preoccupied with the notion of 'economic activity', ${ }^{58}$ the Court does not mention this notion explicitly anywhere in its own reasoning. Instead of concentrating on a possible nexus with gainful employment or remunerated services - as Advocate General Tanchev did in his Opinion - or on a possible normative change brought about by the new Treaty framework, the Court of Justice essentially builds its judgment on an overarching (or at least corollary) right to integrate and on the important role of sports for such integration. ${ }^{59}$

This reasoning represents a significant shift in the responsibilities put on sports organisations, due to the EU free movements rules. It is a clear step away from the prevailing view that these organisations would only be bound to justify their rules concerning sport when these rules could hinder someone in their 'professional' exercise of sports. Instead, they would now be bound to justify also rules that are likely to make amateur sport less attractive for EU citizens. ${ }^{60}$

This shift can of course come to affect other areas than sports in the future. One could imagine that also other private organisations regulating the access to certain recreational activities - such as the Scouts, board games associations or social media platforms - would get new responsibilities under this logic.

\section{OBJECTIVITY SAFEGUARDS ALSO FOR 'PRIVATE' PRIOR AUTHORISATION SCHEMES}

This section is devoted to a specific strand of new potential obligations for private decisionmakers, flowing from the Court's judgment in the TopFit and Biffi case, namely parts of the objectivity safeguards mentioned in section 1.1 of this article. In accordance with this judgment, they would not only be relevant when a domestic public administration establishes a prior authorisation scheme, but also when a private regulator establishes one.

The relationship between national sports organisations and the public authorities varies greatly between the different Member States, ${ }^{61}$ but many of these organisations are established under private law, like the DLV. However, even if the national sports federations are not public authorities, they often enjoy a certain monopolistic position when it comes to

\footnotetext{
${ }^{56}$ Case 36/74 Walrave and Koch EU:C:1974:140, para 4, Case 13/76 Donà EU:C:1976:115, para 12, and Case C-415/93 Bosman EU:C:1995:463, para 73.

57 Parrish and Lindholm (n 51) 1284.

58 Case C-22/18 TopFit and Biffi EU:C:2019:497, paras 18 and 19.

${ }^{59}$ See, in particular, Case C-22/18 TopFit and Biffi EU:C:2019:497, paras 31-33 and 63.

60 ibid, para 47.

${ }^{61}$ See Joined cases C-155/19 and C-156/19 FIGC and Consorzio Ge.Se.Av. ECLI:EU:C:2020:775, Opinion of AG Campos Sanchez-Bordona, paras 27-29.
} 
organising national championships and, in that position, can regulate the access to such championships. There are no EU harmonized rules regarding such access and Advocate General Tanchev noted the diversity of rules concerning the access to national championships and official rankings within the EU. ${ }^{62}$ One form of regulating access to championships or other sports activities could be through a prior authorisation scheme, like the one put into place by the DLV. Pursuant to the rules of this organisation, participation without classification in championships was subject to the approval of the president of the federal committee or the organiser of the event.

As can be understood from paragraph 64 of the judgment in the TopFit and Biffi case, the mere possibility of a refusal, which is inherent to the very nature of a prior authorisation scheme, is enough to qualify the scheme as a restriction on the fundamental freedoms of EU citizens. This is consistent with how national prior authorisation schemes have been treated by the Court of Justice in earlier case-law. In fact, even in cases where the authorisation have been claimed to be no more than a formality, practically all applications being accepted, the Court has recalled that the EU free movement is a 'right whose enjoyment may not be dependent upon a discretionary power or on a concession granted by the national authorities'. ${ }^{63}$

As for the imposition of objectivity safeguards as limits to the legal autonomy of the DLV, it follows from paragraph 65 of the judgment that, such a prior authorisation scheme can, 'in any event', only be justified in the light of Articles 18 and 21 TFEU if it is 'based on objective and non-discriminatory criteria which are known in advance, in such a way as to circumscribe the exercise of the DLV's discretion so that it is not used arbitrarily'. What was initially conceived of as autonomy, hence, start to look like discretion. As authority, the Court refers to paragraph 38 of its judgment in the Analir case. ${ }^{64}$ For the purposes of the current article, suffice it to say that the Court appears to make quite a normative leap here. Contrary to the TopFit and Biffi case, the Analir case concerned a 'prior administrative authorisation scheme', handled by a national public authority, and the interpretation of a piece of secondary EU legislation applying the principle of freedom to provide services. However, this case has, with time, become somewhat of a 'reference of choice' for the Court when it wishes to indicate the need for objectivity safeguards in national prior authorisation schemes. ${ }^{65}$

The Court does not give any specific reasons regarding why the autonomy of a private sports organisation should be limited through the same kind of objectivity safeguards as the discretion of a national public administrative body. However, paragraphs 37 to 39 of its judgment provide the reasoning for why the rules of national sports organisations should be subject to the rules of the Treaty in the same way as public regulations would. Making reference to ample case-law, the Court essentially stated that the freedom of movement for persons and the freedom to provide services would be compromised if the abolition of barriers created directly by the Member States could be neutralised by obstacles resulting from the exercise of the legal autonomy of associations or organisations which are not governed by public law. In this regard, the Court stressed that this principle also applies in

\footnotetext{
62 Case C-22/18 TopFit and Biffi EU:C:2019:181, Opinion of AG Tanchev, paras 44-47.

${ }^{63}$ Case 130/80 Kelderman EU:C:1981:49, para 14 and Case 124/81 Commission v United Kingdom (UHT milk) EU:C:1983:30, para 10.

${ }^{64}$ Case C-205/99 Analir and Others EU:C:2001:107.

${ }^{65}$ See eg Case C-203/08 Sporting Exchange EU:C:2010:307, para 50.
} 
'cases where a group or organisation exercises a certain power over individuals and is in a position to impose on them conditions which adversely affect the exercise of the fundamental freedoms guaranteed under the Treaty'. It can be concluded that this type of reasoning is squarely positioning the effective enforcement of EU law ${ }^{66}$ as the primary (or at least the only available) justification for obliging private decision-makers to infuse their authorisation schemes with objectivity safeguards.

In any event, the Court certainly does not seem to be tied down to doctrinal separations between administrative and private law, ${ }^{67}$ as it takes a pragmatic effects-based approach to what can constitute a restriction on EU free movements and what safeguards are needed to prevent unjustified restrictions. Requiring objectivity safeguards also for private authorisation schemes surely makes sense when the private decision-maker has a monopolistic position and can one-sidedly regulate the rights and freedoms of many actors, since the decisions taken by such an actor would formally be horizontal in nature, but present a vertical unevenness. ${ }^{6}$ In such circumstances, the private regulator needs to be subject to the same EU checks and balances as the public one. ${ }^{69}$ In a similar vein, Timmermans has previously argued for a normative development where the greater the dominant position of the individual or collectively discriminating party or parties, and thus the fewer the alternatives open to the victim of the discrimination, the more likely a finding of discrimination (as sanctioned by EU primary law) would result. ${ }^{70}$

On the topic of normative developments, one could also note that the questions arising in the TopFit and Biffi case did not arise in a national doctrinal void. On the $11^{\text {th }}$ April $2018-$ before the Court's judgment in TopFit and Biffi but after the referring national court in this case had made its request for a preliminary ruling - the German constitutional court handed down a judgment ${ }^{71}$ that also related to private sports organisations and the horizontal effects of fundamental rights, more specifically the right to equal treatment. As a sign of (at least apparent) parallel constitutional developments in the laws of the EU and the Member States, this judgement also imposed uncodified 'administrative law'-type requirements on private law subjects such as sports organisations.

\footnotetext{
66 Parrish and Lindholm (n 51) 1291.

${ }^{67}$ Cf. Jürgen Basedow, 'The Judge's Role in European Integration - The Court of Justice and Its Critics' in Micklitz and Witte (n 12) 79: 'While the Court's critics focus on a transgression of Community competences by the Court, the demarcation of Community and Member State competences is an insufficient and inappropriate yardstick for the Court's practice in many areas of law. In private law in particular the reasonable balancing of the interests of the parties involved is more important. But it appears that the Court is not yet fully aware of the difference in approach that is needed for the various areas of law.'

${ }^{68}$ See Wojciech Lewandowski, 'The Implications of the Recent Jurisprudence of the Court of Justice of the European Union for the Protection of the Fundamental Rights of Athletes and the Regulatory Autonomy of Sporting Federations' (2020) 25 Tilburg Law Review 55.

69 Antoine Duval, 'Guest Editor's Introduction' (2015) 22 Maastricht Journal of European and Comparative Law 172.

${ }^{70}$ C.W.A. Timmermans, 'The Basic Principles' in Kapteyn (n 8) 163

711 BVerfG, Order of the First Senate of 11 April 2018 - 1 BvR 3080/09 -, concerning so called 'stadium bans'. An English version of the judgment is accessible at the following address: < https://www.bundesverfassungsgericht.de/SharedDocs/Entscheidungen/EN/2018/04/rs20180411 1 bvr 308009en.html $>$ accessed 17 December 2020
} 


\section{CONCLUSIONS}

The judgment in the TopFit and Biffi case combines the case-law concerning the right of EU citizens not just to move freely, but to integrate - effectively and without facing disproportionate restrictions - in the Member State they happen to settle down in, with a case-law on horizontal direct effect of the free movement provisions connected to economic activity, and hitherto only applied to private employers or organisations that would regulate the access to the economic activity. As Tanchev's conclusions seem to suggest, this can be regarded as a constitutional quantum leap. It certainly solidifies the EU citizen's right to integrate in her new 'home away from home', when choosing to move from one Member State to another, in the sense that not only the public authorities of her new home - but also certain private decision-makers - will be obliged to provide regulatory frameworks infused with objectivity safeguards. Neither public discretion nor legal autonomy of private regulators may be used to arbitrarily hinder her integration in her new home.

As the title of this article suggests, I would argue that - in light of the Topfit and Biffi case - it would be more appropriate to conceptualize the legal autonomy of private decisionmakers as a regulatory discretion that is subject to EU administrative law requirements, as soon as this decision-maker is powerful enough to hinder the EU free movements.

One should, however, be aware of problems that might arise when subordinating the relations traditionally governed by private law and based on party autonomy to some obligation of justification. As noted by Azoulai, this is potentially disturbing for the social policy of the state but also for the structural features of the national system of private law. ${ }^{72}$

${ }^{72}$ Loïc Azoulai, 'The Case of Fundamental Rights: a State of Ambivalence' in Micklitz and Witte (n 12) 215. 


\section{LIST OF REFERENCES}

Azoulai L, 'The Case of Fundamental Rights: a State of Ambivalence' in Micklitz H-W and De Witte B, The European Court of Justice and the Autonomy of the Member States (Intersentia 2012) 215

Basedow J, 'The Judge's Role in European Integration - The Court of Justice and Its Critics' in Micklitz H-W and De Witte B, The European Court of Justice and the Autonomy of the Member States (Intersentia 2012) 79

C.W.A. Timmermans, 'The Basic Principles' in Kapteyn P.J.G., The Law of the European Union and the European Communities: With Reference to Changes to Be Made by the Lisbon Treaty (4th rev. edn, Kluwer 2008) 163

Duval A, 'Guest Editor's Introduction' (2015) 22 Maastricht Journal of European and Comparative Law 172

DOI: https://doi.org/10.1177/1023263×1502200201

Ericsson A, 'Structural Guarantees - the Union's Last Best Hope against National Arbitrariness' (2010) 13 Europarättslig tidskrift 237

Ericsson A, 'The Role of the Court in Limiting National Policy-Making: Requiring Safeguards against the Arbitrary Use of Discretion' in Lindholm J and Derlén M (eds), The Court of Justice of the European Union: Multidisciplinary Perspectives (Hart Publishing 2018)

DOI: https://doi.org/10.5040/9781509919116.ch-006

Kepteyn P.J.G., 'The Application and Enforcement of Community Law in the National Legal Systems' in Kapteyn P.J.G., The Law of the European Union and the European Communities: With Reference to Changes to Be Made by the Lisbon Treaty (4th rev. edn, Kluwer 2008) $532 \mathrm{f}$

Lewandowski W, 'The Implications of the Recent Jurisprudence of the Court of Justice of the European Union for the Protection of the Fundamental Rights of Athletes and the Regulatory Autonomy of Sporting Federations' (2020) 25 Tilburg Law Review 55

DOI: https://doi.org/10.5334/tilr.193

Mortelmans K.J.M., 'The Functioning of the Internal Market: The Freedoms' in Kapteyn PJG (ed), The Law of the European Union and the European Communities: With Reference to Changes to Be Made by the Lisbon Treaty (4th rev. edn, Kluwer 2008) 636

Parrish R and Lindholm J, 'Horizontal Direct Effect of Union Citizenship and the Evolving Sporting Exception: TopFit' (2020) Common Market Law Review 1283.

Prechal S, 'Free Movement and Procedural Requirements: Proportionality Reconsidered' (2008) Legal Issues of Economic Integration 201 
Ragnemalm H, 'Fundamental Freedoms and Private Action: A New Horizon for EU Citizens?' in Ragnemalm $\mathrm{H}$ and Melin M, EG-Domstolen Inifran: Uppsatser Om Och Kring Rättskipningen Inom EU (Jure 2006) 183

Van den Bogaert S, 'Bosman: One for All ...' (2015) 22 Maastricht Journal of European and Comparative Law 174, $175 \mathrm{f}$

DOI: https://doi.org/10.1177/1023263x1502200202 